\title{
Research on Strengthening Tax Follow-Up Management and Preventing Tax Law Enforcement Risks in the Context of Simplified Administration and Power Decentralization
}

\author{
Meihong Li1 ${ }^{1}$ Hanchun Wei ${ }^{2}$ \\ ${ }^{1}$ Department of Accounting, Jinan University, Guangzhou, China \\ ${ }^{2}$ Local Taxation Bureau of Haizhu District, Guangzhou, China \\ Email: 2379004329@qq.com
}

How to cite this paper: Li, M. H., \& Wei, H. C. (2016). Research on Strengthening Tax Follow-Up Management and Preventing Tax Law Enforcement Risks in the Context of Simplified Administration and Power Decentralization. Journal of Financial Risk Management, 5, 315-325.

http://dx.doi.org/10.4236/jfrm.2016.54026

Received: November 30, 2016

Accepted: December 27, 2016

Published: December 30, 2016

Copyright $\odot 2016$ by authors and

Scientific Research Publishing Inc.

This work is licensed under the Creative

Commons Attribution International

License (CC BY 4.0).

http://creativecommons.org/licenses/by/4.0/

\begin{abstract}
This paper summarizes and analyzes the problems existing in the follow-up management and tax law enforcement in the context of function transformation of tax authorities, simplified administration and power decentralization, and discusses the approach to strengthen the follow-up management and prevent the tax law enforcement risk.
\end{abstract}

\section{Keywords}

Follow-Up Management, Tax Law Enforcement, Risk-Oriented, Tax Risk Management

\section{Introduction}

In recent years, the government China has continuously put forward transformation function, and reduced the decentralization, to further promote the reform of administrative examination and approval system, and the reform of sustained release bonus. The tax authorities, directly facing the market's economic management and administrating law enforcement departments, regarded "streamlining administration and delegating power" as the priority among priorities, actively promoted the transformation of government functions, deepening the reform of tax administrative examination and approval system, and stimulated the vitality of market subjects, increasing power for economic and social development.

However, the simplified administration and power decentralization of tax authorities do not mean the "simple abandonment". In the process, the tax authorities face more 
and more tax-related business into the management in and after the matter. How to strengthen the follow-up management and prevent the law enforcement risks is the challenge for the tax authorities and the key to promote the simplified administration and power decentralization. This paper first analyzes the problems in follow-up management and tax law enforcement of tax authorities in the context of simplified administration and power decentralization, and then discusses the approach to strengthen the follow-up management and prevent the tax law enforcement risks.

\section{The Problems of Tax Authorities in the Following Management and Tax Law Enforcement}

\subsection{The Concept of Modern Tax Administration Has Not Been Fully Established}

The process of tax administrative examination and approval system reform and the continuous promotion of decentralization are not only the process of providing efficiency, optimizing service and convenient service, but also the process of repaying taxpayers (China Institute of Certified Public Accountants, 2015). This process brings a certain degree of incompatibility to the taxpayers and tax authorities, mainly the lack of "security". For example, the previous approval system has no problem after the submission of information for taxpayers, and the risk of liability is transferred to the tax authorities, but now the taxpayer must be fully responsible for the tax-related risks, and the tax authorities will no longer take the responsibility of guarding against risks, instead of taxpayers, and the misstatement, omission and other tax risks will increase more than a lot. For the tax authorities, the prevention and control of law enforcement lacks a strong starting point, and if the taxpayer does not truthfully declare, the follow-up management of tax authorities cannot keep up, while under the tax management resources, it is difficult to ensure that all taxpayers can comply with the full tax law, and the law enforcement risk is very easy to be produced. Therefore, with the decentralization, to ensure that the optimization of services while increasing tax compliance with taxpayers, tax revenue cooperation, taxpayers self-assessment, gap management, tax risk management philosophy and other modern tax management philosophy is particularly necessary.

\subsection{Information Asymmetry between the Two Sides Has Not Been Effectively Solved}

The information asymmetry between the two parties is the common problem in the tax administration. The taxpayer has a comparative advantage over the tax authorities in understanding and mastering its own business information. The taxpayer assesses and confirms the taxpayer's tax return through the taxpayer's return, the information obtained from the on-the-spot investigation and other information obtained from the taxpayers. With the rapid economic and social development and the rapid growth of the number of taxpayers, tax concealment and increasing mobility, the tax authorities is also difficult to grasp the changes in tax sources in a timely manner. At the same time, 
the taxpayer's information is scattered in different government agencies, departments and financial, intermediary agencies and other public service companies. Therefore, how to obtain and effectively use the third-party information is the key to solve the problem of information asymmetry. At present, in the tax administration system of developed countries, the acquisition of taxpayer's information has had a set of highly specialized and comprehensive taxation management system, including the establishment of specialized agencies and personnel, in addition to the corresponding legal system guarantee, a high degree of information support, the full cooperation between government departments, a wide range of social collaboration organizations. In China, the third-party information collection and application is still in its infancy: First, the State Administration of Taxation has issued relevant guidance on third-party information collection and application, such as "Guidance of State Administration of Taxation on the Promotion of Property Tax Third-party Information Collection and Application" (SZF [2015] 52), but the tax authorities at all levels mainly delegate the third-party information collection and application to the grassroots tax authorities; second, the grassroots tax authorities have made some achievements in recent years in the third-party information collection and application, but most of them are self-exploration without the systematic and unified planning and arrangements, and the collection of information is relatively rough and decentralized. Third, although the "Tax Collection Law Implementation Rules" provides that "local people's governments at all levels should actively support the tax system information construction, and organize relevant departments to achieve the sharing of relevant information", but there is a certain degree of difficulty in the cooperation between the tax authorities and other government departments, and the communication and cooperation are not enough deep.

\subsection{Follow-Up Management Tools Have Not Fully Matched Yet}

In the context of tax decentralization and administrative approval system reform, more and more tax-related matters will be transferred to supervision after the matter, and strengthening the follow-up management is an inevitable requirement. However, from the perspective of current practice of tax collection and management, the follow-up management measures of tax authorities have not been fully matched with the administrative examination and approval system reform of decentralization, and there is a very large space for improvement, as follows:

\subsubsection{Follow-Up Management Process and Approach Have Not Fully Matched Yet}

The tax management is a systematic process; the greater the tax prior management is improved, the more the issues and scope of follow-up management will be. In the process of simplified administration and power decentralization, it is often easier to focus on the improvement of prior management links. At present, the follow-up management of tax-related matters is in the exploration of tax authorities at the grassroots level, and the non-unified management and limited methods and means are easy to cause disputes and contradictions between the two sides, and the specific process and 
method are lacked "from top to bottom".

\subsubsection{Relevant Resources of Follow-Up Management Have Not Been Effectively Integrated}

Different from the previous examination and approval system, more and more matters are transferred into the record system (handle before review), and the follow-up tax-related matters will usually involve organizations or individuals of different taxpayers, different tax authorities in different regions, and due to the information asymmetry between the two sides, and the linkage management is lacked in the tax authorities within the various departments, so there is no unified information platform, and it is easy to induce taxpayers to take advantage of the time difference and the lack of linkage management, the "management vacuum", to avoid tax. If the transfer of individual equity is handled well, in accordance with the new process, as long as the taxpayers submit complete information and declaration record with equity transfer (zero declaration), the tax authorities must handle the equity transfer business. At the beginning of the implementation of new process, there are many taxpayers and tax intermediaries that use the business and carry out follow-up management in the same day, and then handle the equity change immediately after the business. As a result, the original jurisdiction of the tax authorities have not had time for follow-up management, companies have moved out of its jurisdiction, and the new jurisdiction of the tax authorities do not know the company has handled the equity change procedures. In the absence of linkage management and non-shared information, it is most likely to cause the loss of personal income tax in equity transfer.

\subsubsection{The Leading Department for Follow-Up Management Has Not Been Fully Defined Yet}

In the current practice of tax collection and management, the tax authorities, tax collection and management departments have different requirements for the follow-up project management, which is easy to cause the multiple layouts, crossed or blurred responsibility. At the same time, the risk control functions of tax assessment departments newly set up by local tax authorities is not entirely clear or different from each other, which lacks the top-level design. Therefore, establishing risk control center, including the relevant follow-up management issues into the risk control and management, leading the deployment by risk control center have become an inevitable requirement for policy implementation and management.

\subsection{Collection and Management and Enforcement Tools Have Not Been Strengthened Yet}

Although the tax administration law has given the tax authorities some law enforcement authority, the current actual work in the organs of law enforcement means are still limited, such as land value-added tax settlement, enterprise income tax follow-up management, personal equity transfer follow-up management of tax problems, as well as the unclear current policy and backward management means. Take the equity transfer of personal income tax policy as an example. In the past, the tax authorities had suf- 
ficient time and procedures to verify and investigate the transfer of the parity or lowprice transfer. The recovery of the personal income tax on equity transfer was relatively easy and the cooperation of taxpayers was high. The transfer of the individual is often difficult to get in touch, and the transferee and the transfer of enterprises are reluctant to cooperate with, although withholding agents have the means to punish. The transfer of relevant taxes and fees are still difficult to be recovered. Therefore, to further simplify the creation of decentralization space, we need to further strengthen the collection and law enforcement tools to enhance the level of law enforcement and effectiveness.

\section{Using the Risk Management Theory and Method to Establish the Risk-Oriented Tax Management System}

Establish the risk-oriented tax management system; that is, on the basis of a comprehensive analysis of taxpayers, according to the different types and different levels of tax risk, rationally allocate the tax management to enhance resources through the use of risk management theory and methods, guard against tax risks and enhance the level of collection and management through risk reminder, tax assessment, tax audit, anti-tax avoidance investigation, tax audit and other risk response means ( $\mathrm{Wu}, 2014)$.

\subsection{Establish the Modern Tax Management Concept}

Modern tax management concepts include the tax trust cooperation, taxpayers' selfassessment, gap management and tax risk management philosophy (Teaching Materials Writing Group of State Administration of Taxation, 2016). In terms of decentralization, this paper argues that it is necessary to set up the tax management concept with taxpayers' self-assessment and tax risk management as the core.

The purpose of taxpayers self-assessment concept is mastered in the taxpayer; that is, let taxpayers understand that the declaration is the taxpayer's own thing, fulfilled by the taxpayer, and the tax authorities should be responsible for providing the necessary tax services, on behalf of the state, examining, confirming or adjusting the taxpayers' performance of their obligations in accordance with the authenticity and accuracy of declaration. The process of establishing this concept is to strengthen tax publicity and education and to provide taxpayers with the ability to comply with the tax law: one is to strengthen publicity, change the concept of taxpayers, let them aware of the risks and responsibilities; the second is to strengthen the taxpayers' Business knowledge training; third is the way the Internet + tax, through the We Chat, microblog, websites, 12,366 and other channels to promote decentralization of tax-free in a timely manner, especially for tax risk, provide appropriate tax risk reminder services, strengthen the push, so that taxpayers can understand and master the policies and regulations, and reduce tax risk in a timely manner.

The reason for establishing the concept of tax risk management is that the fundamental purpose of tax collection and administration is to promote tax compliance, but in order to ensure that all taxpayers comply with the tax law, the tax administration resources are always insufficient, and so it will result in law enforcement risks. Therefore, 
in order to promote the compliance with efficiency, it is necessary to allocate the limited management resources to the taxpayers with higher risk management to realize the transition from "all taxpayers" to "taxpayers with risk". The purpose of this idea is to provide guidance for the optimal allocation of organizational resources, improve the efficiency of collection and management, while avoiding and preventing unnecessary risk of law enforcement.

\subsection{Using Risk Management Theory}

In the tax risk management system, forecast the tax authorities through the risk prior to taxpayer noncompliance occurred, under the premise of ensuring the rational allocation of collection resources under the avoidance of possible tax risk according to the prediction results, so as to reduce the loss of tax revenue, lower taxes and the gap should be tax. It has important practical significance for improving the taxpayer's tax compliance, reducing the cost of tax collection and management, building a harmonious relationship between tax collection and management.

\subsubsection{Definition of Tax Risk Management}

Bartram, Brown, and Fehle (2009) proposed tax risk management refers to the process of tax administration, to maximize the collection effect with minimal consumption of resources, which is in low cost under the condition of the maximum reduction of the size and risk of administrative law enforcement of tax revenue, so as to ensure the smooth collection of revenue. Johns (2011) on the basis of the above definition for the classification system of tax risk management, including risk of tax law enforcement risk, compliance risk, tax risk, risk and risk of foreign reform. And the risk management process is divided into risk planning, risk identification, risk assessment, risk response, and several other aspects.

In Chinese, Li Hanwen (2008) the tax risk is defined as the taxpayer, tax authorities and tax related subjects in the influence of the subjective purpose of the measures taken, the two sides may face the possibility of the subject, contrary to the expected target deviation is generated, will give the main tax resulting in the loss of economic interests (Li, 2008).

\subsubsection{Classification of Tax Risk Management}

Zeng Changsheng (2011) divided tax risk into system risk, income risk and expenditure risk. According to the content classification, can be divided into administrative risk, criminal risk, economic risk, the risk of loss of power. According to the genetic classification, can be divided into legislative risk, policy risk, management risk, taxpayer behavior risk $(\mathrm{Hu}, 2015)$.

\subsubsection{Establish Tax Risk Management}

Focus on the risk management, change management, and optimize the allocation of resources. In the general trend of decentralization, the previous management is difficult to fully implement the quality and quantity in place, even if due diligence cannot be completed, causing the law enforcement risks. In addition, the daily affairs will also 
take up a lot of resources, resulting in a low proportion of risk management personnel, a large number of risk analysis, tax assessment task cannot be effectively addressed. Therefore, the risk-oriented management with the resources in targeted and more efficient matters can achieve the change in management and greatly reduce the risk of law enforcement.

First, set up the risk management leading department and improve the risk management process. Through the establishment of the risk management leading department (such as the risk control center) for the overall planning of follow-up management, clear the division of responsibilities of various departments to strengthen cooperation, and avoid the fragmented and duplication of work. On this basis, set up a set of process specifications, risk management process system with tax linkage management for the content, including risk identification, ranking, risk task management, risk response, process monitoring and performance evaluation, strengthen follow-up management in the system level, prevent law enforcement risks. For the "tax system" from the "examination and approval system" to the "recording matters", develop and improve follow-up management processes and methods based on research and analysis from top to bottom in a timely manner.

Second, rely on modern information technology and improve risk management. The rapid development of modern information technology has opened up a new space for the tax authorities to carry out risk management. For example, establish the financial follow-up management and classification management as one of the risk management platforms for automatic information exchange through third-party data applications, data comparison within the system, large data management, etc., push the audit process, effectively find the doubtful point, and promptly correct and deal with taxpayers' mistakes. Among them, the follow-up management establishes the appropriate follow-up monitoring indicators for all types of tax-related business, in order to achieve tax-related aspects, timely detect the existing risks and weak links; set up the risk index system, classify the various industries and the corresponding risk points, determine the risk link indicators and coefficients, respectively, and use the desk assessment, routine inspection, special inspection methods to verify the risk of investigation points (Notice of State Administration of Taxation on Further Strengthening the Administration of Tax Risk, 2016).

Third, improve follow-up management quality and efficiency with the help of social intermediary forces. Under the existing human resources, tax collection and the management system has not yet been fully adjusted, the relevant tax-related business in the follow-up management of the appropriate above with the accounting firm, tax accountants, asset evaluation agencies and other social intermediary forces, is a good choice. On the other hand, the tax authorities can also absorb the advanced experience in taxation and other aspects of learning social intermediary agencies in this process, and the tax authorities can also improve the efficiency of the tax administration, so as to improve the quality of follow-up management, improve staff quality, and guard against law enforcement risks. For example, the bureau hired tax accountants in 2015 to par- 
ticipate in enterprise income tax management and 13 value-added tax liquidation projects, and the payment service cost of 498,600 yuan yielded about 18.79 million yuan of enterprise income tax examination and tax, land value-added tax settlement should be about 81.72 million yuan, and the input-output ratio was up to 1:201, so the effect was very significant.

\subsection{Strengthen the Ability of Information Management and Taxation}

To strengthen the tax information management is to take full advantage of modern information technology means to solve the problem of information asymmetry between the two sides, so as to focus on the collection and analysis of tax-related information, establish the tax risk management concept, perfect the tax source management, and strengthen the integration of business and technology, thereby increasing the level of tax collection and management. It can be carried out from three aspects:

1) Obtain the third-party information and data. Third-party information is all conducive to safeguarding the tax revenue, the tax collection and management order of all kinds of fair and impartial information. The tax authorities may establish and perfect the information exchange mechanism with the government department from the top to the bottom, establish or clarify the specialized information collection department, sort out the clear information source department according to the setting situation of each government function department, and combine the information collection and management work, and define the categories, projects, content, content, frequency of collection, acquisition and storage standards. On this basis, establish a unified data collection platform and data repository, achieve intelligent collection and storage of thirdparty information and ultimately realize the third-party information real-time interaction and automatic interaction. In addition to the information of various government departments, also pay attention to the daily management of the unconventional intelligence gathering and media network information collection, through the establishment of appropriate information collection mechanism, the responsibility, and use advanced network crawling technology, access to information on a comprehensive interpretation, classification and collation.

2) Strengthen the analysis of third-party information and data applications. Tax authorities can rely on modern information technology, through the use of supporting the use of advanced intelligent analysis tools, through the establishment of analytical methods to enhance the effectiveness of third-party information applications. For example, establish the third-party information and related tax revenue data between tax revenue analysis and forecasting; carry out the tax collection and management of quality analysis to find the weak links in the collection and management to prevent loss of tax revenue to enhance the level of collection and management; improve the risk index system of each tax, build risk management model, timely find the tax risk points, and further promote risk management.

3) Improve the knowledge management level. For example, refer to the judiciary case database, establish the tax domain management knowledge base, record the tax admin- 
istration practice, achieve the sharing of tax management knowledge and form the cycle of knowledge with the wisdom of community.

\subsection{Other Methods of Strengthening the Tax Follow-Up Management and Prevent Law Enforcement Risks in the Context of Decentralization}

According to the above, the problem of information asymmetry, the lack of modern tax management concept, the lagging tax administration and limited collection and enforcement means make the problem of follow-up management and law enforcement risk particularly prominent in the context of decentralization, which is not conducive for the tax authorities to further promote the decentralization. To further promote the decentralization, it is necessary to solve the above problems one by one.

\subsubsection{Promote the National Tax Cooperation}

As the two systems under the leadership of the State Administration of Taxation, it is necessary to strengthen the exchange and cooperation between the government and the local tax authorities should strengthen tax collection, exchange information, share resources and adapt to the reform of tax collection and management system. The tax authorities also explore cooperation with other government departments. Management, exchange the beginning of the contract. From the initial land tax authorities to use the state tax information exemptions, tax rebates, tax information to strengthen the city maintenance and construction tax risk management to the two sides held a joint meeting on a regular basis to share data and carry out joint taxation, "Reform Program of Deepening the National Tax, Land Tax Collection and Management System", "Specification of Cooperation between State Administration of Taxation and Local Tax Bureau (Version 1.0)", "Specification of Cooperation between State Administration of Taxation and Local Tax Bureau (Version 2.0)" and "Specification of Cooperation between State Administration of Taxation and Local Tax Bureau (Version 3.0)". On the one hand, the tax authorities should take this opportunity as an opportunity to explore the new management methods and new concepts brought about by the cooperation of state and local taxes, and prevent the risks of law enforcement. On the other hand, the tax authorities should accumulate and summarize the valuable experiences of government departments' exchanges and cooperation; other government departments can promote a wider range of collaborative management.

\subsubsection{Enhance the Comprehensive Tax Ability}

Comprehensive taxation emphasizes that the tax authorities should provide tax compliance as the main objective through strengthening the cooperation between the government departments, industry associations, social intermediary and other social organizations, and should form the government leaders, tax authorities, departments, social participation, judicial security, comprehensive information support tax and tax care network (Fang, 2016). Improving the comprehensive taxation capacity can not only expand the information resources available to the tax authorities, but also strengthen 
the collection and management of tax authorities. It can be carried out from two aspects:

First, improve the information sharing mechanism through the support of local governments, strengthen cooperation with government departments, establish and improve the information sharing mechanism, and expand the scope of information sharing in industry associations, intermediaries and other fields.

Second, improve the social credit system. Through the establishment of a unified assessment system for tax credit loss, a clear taxpayer range of bad record and dishonest taxpayer standards, rely on information platform, form the "four in one" tax credit management system through the integration of internal and external information on the taxpayer bad record, dishonest taxpayer blacklist, taxpayer compliance and other information management, and integrate the construction of the government credit system (He, 2015). At the same time, strengthen the application of tax credit management system, the credit management results for tax services, tax law enforcement, bank credit, industry management, and continuously improve the social impact of tax credit management.

\section{Summary}

The so-called "decentralization, combination of delegation and regulation, and optimize service" are to utilize the modern advanced information technology to reform the collection and management system, carry out risk management, carry out the contract of national and local taxes and coordinate management, prevent tax law enforcement risk, constantly strengthen supervision after the event, ultimately optimize the tax services, and promote taxpayers to comply with the process. In short, the decentralization brings problems to the tax authorities in follow-up management and law enforcement risks at the same time, and promotes the tax authorities to continue to improve it.

Although this paper put forward some strengthening of the follow-up management, direction and method of prevention and control of risk, but failed to further put forward mode and specific measures, also temporarily failed to find the corresponding typical case for reference, the need for further research and discussion.

\section{References}

China Institute of Certified Public Accountants (2015). Tax Law. Beijing: Economic Science Press.

Fang, R. (2016). Tax Law Enforcement Risk Management in Grass-Roots Tax Department. Thesis, Shandong University of Finance, Ji'nan.

He, M. (2015). Law Enforcement Risk and Preventive Measures for Grass-Roots Tax Authorities. Thesis, Suzhou University, Suzhou.

Hu, X. B. (2015). Research on the Problem of Tax Risk Management. Thesis, Shandong Agricultural University, Tai'an.

Li, H. W. (2008). Definition and Harm of Tax Risk. Tax Research, 8, 66-68.

Notice of State Administration of Taxation on Further Strengthening the Administration of Tax Risk (2016). No. 54. 
Wu, X. D. (2014). Tax Administration. Beijing: China Renmin University Press,

Zeng, C. S. (2011). Analysis on the Effective Implementation of Tax Risk Management from the Angle of Information Management Optimization. Tax Research, 83-86.

Bartram, S. M., Brown, G. W., \& Fehle, F. R. (2009). International Evidence on Financial Derivatives Usage. Financial Management, 38, 185-206.

https://doi.org/10.1111/j.1755-053X.2009.01033.X

Johns, R. (2011). Study on the Integration of Risk Management Framework and Tax Risk Prevention (pp. 1294-1297). 2011 International Conference on Engineering and Business.

Submit or recommend next manuscript to SCIRP and we will provide best service for you:

Accepting pre-submission inquiries through Email, Facebook, LinkedIn, Twitter, etc.

A wide selection of journals (inclusive of 9 subjects, more than 200 journals)

Providing 24-hour high-quality service

User-friendly online submission system

Fair and swift peer-review system

Efficient typesetting and proofreading procedure

Display of the result of downloads and visits, as well as the number of cited articles

Maximum dissemination of your research work

Submit your manuscript at: http://papersubmission.scirp.org/

Or contact jfrm@scirp.org 